\title{
PEMANFAATAN LIMBAH PETERNAKAN KAMBING PERANAKAN ETAWA (PE) UNTUK MENDUKUNG USAHA TANI PEKARANGAN
}

\author{
Rama Andika Tri Prakasa1, Yuliati Ramdiani ${ }^{1}$, M. Hilman Humaidi², Dedi Hardianto ${ }^{3}$, Fifi Rosalina ${ }^{4}$, \\ Abdul Rismawansyah ${ }^{5}$, \\ dan Muhamad Ali*
}
${ }^{1}$ Fakultas Peternakan, ${ }^{2}$ Fakultas Teknik, ${ }^{3}$ Fakultas Pertanian, ${ }^{4}$ Fakultas Hukum, ${ }^{5}$ Fakultas Keguruan dan IImu Pendidikan, Universitas Mataram, JI. Pendidikan No. 37, Mataram, NTB.
*Penulis korespondensi: $\underline{m}$ ali@unram@ac.id

\begin{abstract}
ABSTRAK. Desa Lepak Timur Kecamatan Sakra Timur Kabupaten Lombok Timur telah dijadikan sebagai sentra Kambing Peranakan Ettawa. Namun, kebiasaan masyarakat yang membuat kandang di sekitar pemukiman menyebabkan permasalahan sanitasi. Untuk itu, melalui kegiatan ini telah dilakukan penyuluhan dan upaya pemanfaatan limbah sebagai bahan pembuatan pupuk organik. Hasil kegiatan menunjukkan tingginya animo masyarakat untuk memanfaatkan limbah peternakan kambing PE sebagai pupuk. Hal ini disebabkan karena kebutuhan pupuk petani di Desa Lepak Timur sangat tinggi terutama untuk tanaman tembakau dan tanaman holtikultura. Melalui kegiatan ini, pemanfaatan limbah ternak kambing PE telah dilakukan dan diharapkan dapat mensubstitusi penggunaan pupuk komersial yang sering sulit diperoleh dan berharga mahal.
\end{abstract}

Kata kunci: kambing peranakan ettawa, limbah, pupuk organik, usaha tani pekarangan.

\begin{abstract}
Lepak Timur Village, East Sakra District, East Lombok Regency has been used as the center of the Ettawa Breed Goat. However, the habits of people who make cages around settlements cause sanitation problems. Therefore, through this activity counseling and efforts to utilize waste as material for making organic fertilizer have been carried out. The results of the activity showed the high public interest to utilize PE goat farm waste as fertilizer. This is because the fertilizer needs of farmers in Lepak Timur Village are very high, especially for tobacco plants and horticulture plants. Through this activity, the use of PE goat waste has been carried out and is expected to substitute the use of commercial fertilizers which are often difficult to obtain and expensive.
\end{abstract}

Keywords: ettawa peranakan goat, waste, organic fertilizer, yard farming

\section{PENDAHULUAN}

Desa Lepak Timur merupakan salah satu desa yang ada di Kecamatan Sakra Timur yang berada di Kabupaten Lombok Timur. Desa Lepak Timur termasuk urutan nomer 303 dari 1137 kelurahan yang ada di Propinsi Nusa Tenggara Barat. Adapun batas territorial Desa Lepak Timur sebelah Utara Desa Gereneng/Gereneng Timur (Kec. Sakra Timur), sebelah Selatan Desa Surabaya Utara (Kec. Sakra Timur), sebelah Barat Desa Lepak (Kec. Sakra Timur), dan Sebelah Timur Desa Kerta Sari (Kec. Labuhan Haji) (Anonim, 2017).

Desa Lepak timur adalah sentral peternakan Kambing Peranakan Etawa (PE) yang sedang digalakan oleh kepala Desa Lepak Timur untuk mengurangi angka pengangguran yang ada di Desa tersebut, meningkatkan Sumber Daya Manusia (SDM) yang berkualiatas yang mampu memanajemen pemeliharaan Kambing Peranakan Etawa (PE), dan pemerintah juga mempunyai 
keinginan yang besar untuk membangun dari pesisir, maka dari itu kepala Desa Lepak Timur membuat sentral peternakan Kambing PE yang sudah berlangsung \pm 1 tahun.

Satu Desa Satu Product atau "One Village One Product" adalah pendekatan pengembangan Potensi daerah di satu wilayah untuk menghasilkan satu produk kelas global yang unik khas daerah dengan memanfatkan sumber daya lokal. Satu desa sebagaimana dimaksud dapat diperluas menjadi kecamatan, kabupaten/kota, maupun kesatuan wilayah lainnya sesuai dengan potensi dan skala usaha secara ekonomis. "One Village One product" (OVOP) adalah pendekatan pengembangan potensi daerah untuk menghasilkan satu produk kelas global yang unik dan khas dengan memanfaatkan sumber daya lokal.

Keinginan pemerintah menjadikan gerakan "Satu Desa Satu Produk" atau "one village one product" (OVOP) sebagai program nasional memang patut didukung. Sebab, secara konseptual maupun praktis, di NTB khususnya pulau Lombok, program OVOP amat menjanjikan. OVOP bisa diandalkan sebagai gerakan swadaya dalam rangka peningkatan kesejahteraan masyarakat serta menjadi wahana revitalisasi ekonomi daerah. Karena itu pula, OVOP bisa menjadi metode untuk membendung arus urbanisasi. Dengan OVOP, warga desa terkondisi tak memiliki cukup alasan untuk mencari penghidupan ke perkotaan. Sebab, pekerjaan dengan penghasilan yang relatif mensejahterakan tersedia di desa. OVOP memungkinkan kegiatan ekonomi terpicu dan terpacu berkembang sesuai dengan potensi dan keunggulan desa setempat.

Tujuan dari Satu Desa Satu Produk atau "One Village One Product" adalah pendekatan pengembangan Potensi daerah di satu wilayah untuk menghasilkan satu produk kelas global yang unik khas daerah denga memanfatkan sumber daya lokal. Satu desa sebagaimana dimaksud dapat diperluas menjadi kecamatan, kabupaten/kota, maupun kesatuan wilayah lainnya sesuai dengan potensi dan skala usaha secara ekonomis. OVOP adalah pendekatan pengembangan potensi daerah untuk menghasilkan satu produk kelas global yang unik dan khas dengan memanfaatkan sumber daya lokal (Adriani, 2014).

\section{ANALISIS PERMASALAHAN}

Kambing PE merupakan salah satu idola para peternak Kambing di NTB karena peminatnya dipeternak untuk dibudidayakan meningkat sangat pesat dari tahun ke tahun. Berdasarkan Angka pada tahun 2015 populasi kambing di NTB tercatat sebanyak 576.125 ekor sedangkan Kambing dikirim ke luar daerah dengan tujuan yaitu Kalimantan Selatan, Kalimantan Timur, Kalimantan Tengah, Sulawesi Selatan sebanyak 2.420 ekor. Hal ini memberikan dampak yang positif bagi peternak Kambing PE khususnya di Lombok.

Meningkatnya preferensi masyarakat beternak kambing PE karena kualitas dari Kambing PE dan harganya yang cukup tinggi. Selain itu juga Kambing PE mempunyai kelebihan yaitu pertumbuhan cepat dan ukuran tubuh yang lebih besar dibanding Kambing Kacang. Namun hingga saat ini peternakan yang ada di NTB masih berbasis tradisional yaitu memelihara kambing dalam jumlah rendah atau sedikit. Kambing merupakan ternak ruminasia kecil yang sangat mudah untuk dipelihara dan dikembangkan dari pada ternak ruminansia besar lainya terutama Sapi dan Kerbau. Kambing termasuk dalam polimorfisme yaitu beranak lebih dari satu dan beranak dua kali dalam setahun sehingga potensi untuk dikembangkan lebih mudah dan efisien. Faktor utama yang menjadi permasalahan yaitu bibit dan pemeliharaan yang belum optimal di tingkat petani-peternak, manajemen pengelolaan pakan yang kurang optimal, kurangnya kesadaran peternak melakukan sanitasi dan Biosecurity pada pemeliharaan ternak Kambing. 
Pada kegiatan ini telah dilakukan penyuluhan dan upaya pemanfaatan limbah peternakan kambing PE sebagai bahan pembuatan pupuk organik. Melalui kegiatan ini, pemanfaatan limbah ternak kambing PE telah dilakukan dan diharapkan dapat mensubstitusi penggunaan pupuk komersial yang sering sulit diperoleh dan berharga mahal.

\section{SOLUSI YANG DITAWARKAN}

Penyuluhan pemanfaatan limbah Peternakan Kambing PE dilakukan di Kantor Desa Lepak Timur dengan narasumber dari dosen-dosen Fakultas Peternakan Universitas Mataram. Selain itu juga didatangkan narasumber dari Puskesmas Desa Lepak Timur dan Mentri Kesehatan Desa Lepak Timur. Adapun peserta terdiri dari semua peternak Kambing PE dan pemuda desa yang tergabung dalam kelompk karang taruna.

Kegiatan penyuluhan dilanjutkan dengan praktek pembuatan pupuk organik berbahan utama limbah peternakan Kambing PE. Kegiatan diawali dengan pengumpulan limbah dan pemisahan dengan limbah padat, berupa ranting-ranting pohon. Limbah tersebut kemudian dicampur dengan abu sekam (1:2) untuk kemudian disemprot dengan probiotik Bacillus. Pemeraman dilakukan di dalam lubang tanah selama 2 minggu. Setelah itu, limbah tersebut diangkat dan dicampur dengan tanah gembur untuk kemudian dimasukkan ke polybag.

Untuk meningkatkan kapasitas pekarangan, telah dihasilkan rak bambu sebagai tempat polybag. Polibag kemudian ditanami dengan bibit cabe dan tomat untuk kemudian diletakkan di atas rak budidaya. Proses penyiraman dilakukan sehari sekali (sore) hari untuk menjaga kandungan air media.

\section{HASIL DAN PEMBAHASAN}

Kegiatan penyuluhan pemanfaatan limbah Peternakan Kambing PE telah dilakukan di Kantor Desa Lepak Timur. Adapun narasumber didatangkan dari dosen Fakultas Peternakan Universitas Mataram, yaitu Prof. Dr. Ir. Soekardono, SU dengan materi berjudul Manajemen Agribisnis Kambing PE, dan Muhamad Ali, Ph.D dengan materi Pemanfaatan Limbah Peternakan Kambing PE sebagai Pupuk Organik. Selain itu juga didatangkan narasumber dari Puskesmas Desa Lepak Timur dan Mentri Kesehatan Desa Lepak Timur dengan materi menyangkut Sanitasi dan Kesehatan Hewan.

Kegiatan penyuluhan diikuti oleh peserta dari kalangan ibu-ibu rumah tangga yang merupakan istri para peternak kambing PE. Hal ini disebabkan karena sebagian besar peternak sedang mengambil hiajuan pakan ternak di sawah ataupun sedang mengerjakan penanaman tembakau. Photo penyuluhan dan praktik pembuatan pupuk organik yang melibatkan masyarakat dapat dilihat pada Gambar 1. Pada acara penyuluhan juga dirintis upaya koleksi limbah peternakan Kambing PE secara berkelompok dengan melibatkan Badan Usaha Milik Desa (BumDes) Desa Lepak Timur. Kepala Desa akan mendesain usaha pembuatan pupuk organik yang akan dikelola BumDes dengan menggunakan alokasi dana desa. Para peternak dianjurkan mengumpulkan limbah peternakannya dan membawa ke BumDes untuk ditukar dengan pulsa listrik. Melalui metode ini, para peternak sangat termotivasi untuk melakukan pengumpulan limbah. 

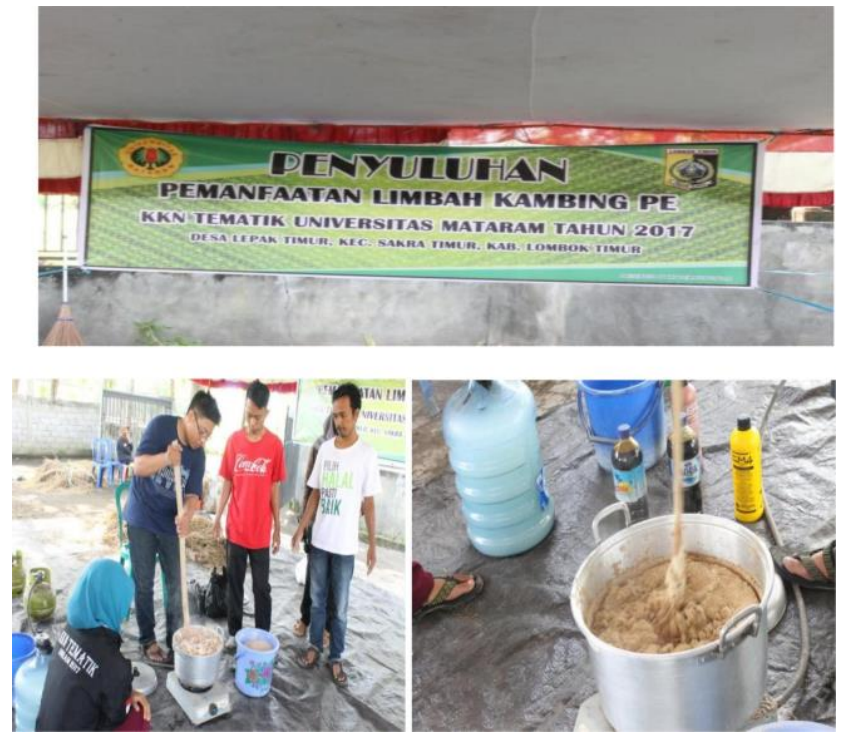

Gambar 1. Penyuluhan pemanfaatan limbah peternakan Kambing PE dan praktek pembuatan pupuk organik berbahan limbah peternakan kambing PE

Kegiatan penyuluhan dilanjutkan dengan praktek pembuatan pupuk organik berbahan utama limbah peternakan Kambing PE maupun sapi yang dipandu oleh mahasiswa KKN Universitas Mataram. Sebagai mikroba pemecah serat, telah digunakan bakteri Bacillus amyloliquefaciens subsp. plantarum yang disinyalir memiliki kemampuan memecah serat, mengikat N, serta memecah komplek posfat (Ali et al., 2018). Kegiatan berlangsung sangat efektif karena tingginya minat untuk menghasilkan pupuk guna memenuhi kebutuhan sendiri.

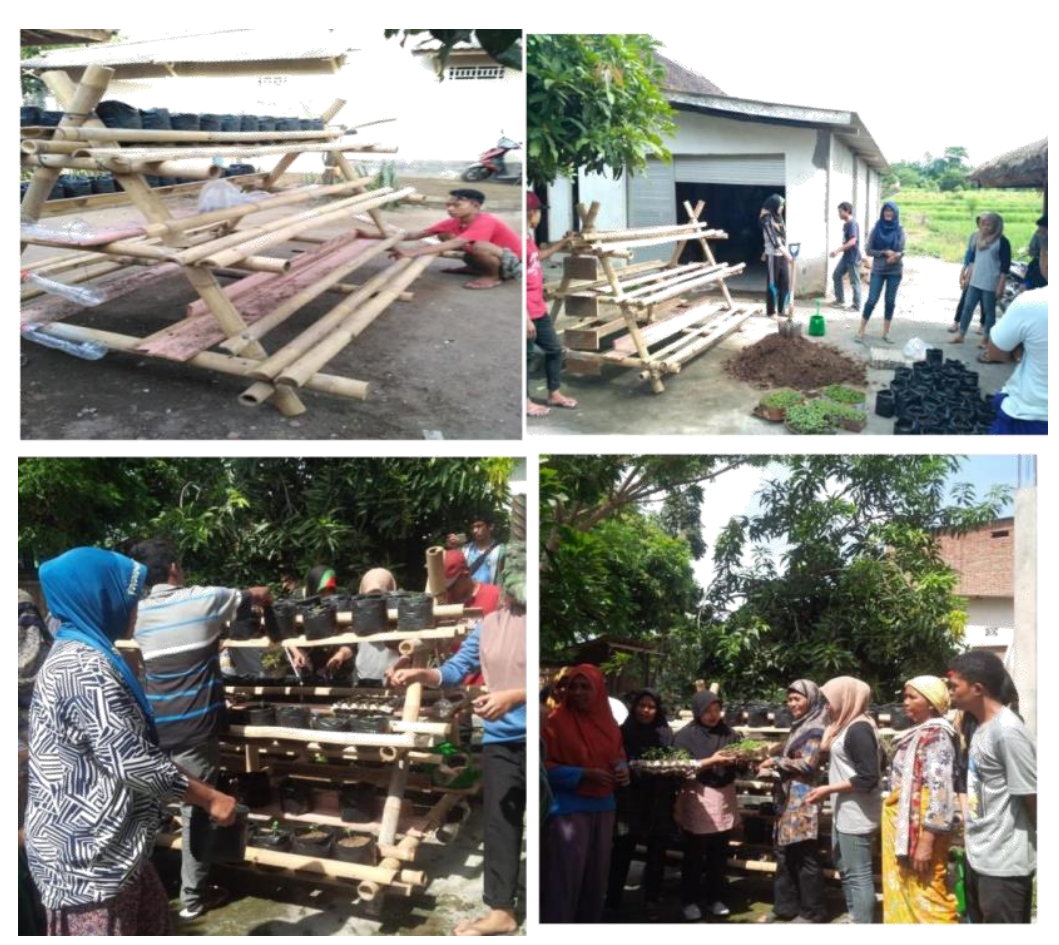

Gambar 2. Proses pembuatan rak budidaya pekarangan dan uji coba penggunaan pupuk organik 
Penggunaan bakteri $B$. amyloliquefaciens subsp. plantarum dalam pembuatan pupuk organik juga diharapkan dapat menghasilkan bio-organik yang dapat merangsang perkembangan bakteri Rhizobium. Ali (2016) menyatakan bahwa penggunaan B. amyloliquefaciens subsp. plantarum dapat menghasilkan Bio-organic fertilizer (BIOs) plant growth-promoting rhizobacterium (PGPR). Ichsan et al. (2016) menyatakan bahwa keunggulan pupuk bio-organik plus PGPR yang dihasilkan ini antara lain: 1) mengandung bakteri fungsional ( $B$. amyloliquefaciens sub. plantarum) yang akan terus hidup, berkembang biak, dan bermanfaat bagi tanaman, 2) memiliki tambahan kandungan protein yang merupakan persyaratan pupuk organik berkualitas tinggi, 3) adanya bakteri $B$. amyloliquefaciens sub. plantarum dapat membantu fiksasi nitrogen dari udara bebas, meningkatkan kelarutan unsur hara yang dikandung manur ayam petelur sehingga meningkatkan ketersediaannya untuk tanaman, 4) mengandung PGPR yang berfungsi menyediakan hormon pertumbuhan dan mencegah penyakit tanaman.

Untuk mengoptimalkan ruang tanam di pekarangan, telah diperkenalkan pembuatan rak budidaya bertingkat yang dibuat dari bambu (Gambar 2). Penggunaan rak budidaya bertingkat ini dapat memperluas areal budidaya terutama di pekarangan yang sempit. Bibit-bibit tanaman, tamana tomat dan cabe, telah ditanam dengan bahan utama media pupuk organik yang dicampur dengan tanah yang subur dengan perbandingan 1:3.

Kegiatan ini mendapat perhatian masyarakat di Desa Lepak Timur yang sebagian besar hidup sebagai petani. Melalui kegiatan ini telah dihasilkan beberapa kegiatan produktif, diantaranya:

1. Pemanfaatan limbah peternakan menjadi produk yang bernilai pasar

2. Revitalisasi BumDes

3. Optimalisasi fungsi pekarangan

4. Produksi beberapa kebutuhan pokok (cabe dan tomat) secara mandiri

5. Kebersihan lingkungan

Pupuk organik yang telah dihasilkan juga telah dimanfaatkan secara luas untuk pupuk tanaman-tanaman di sawah. Karena Desa Lepak Timur hanya dapat menanam padi 1x per tahun, maka kegiatan penamanam tanaman-tanaman lain selesai panen padi dapat didukung oleh keberadaan pupuk yang mudah dibuat dan berbahan baku materi lokal. Untuk itu, kegiatan ini dapat mendukung penyediaan pupuk organik untuk memenuhi kebutuhan sendiri. Padusung (2015) menyatakan bahwa penggunaan pupuk organik dapat mereduksi penggunaan pupuk anorganik yang memiliki banyak kelemahan. Target ke depan dari BumDes adalah menghasilkan pupuk organik dala skala besar untuk dijual ke desa-desa lain. Sehingga dengan pelaksanaan kegiatan ini akan dapat mendukung "sustainable agricultutal" bagi petani dengan memanfaatakn sumber daya yang terbuang melalui inovasi yang berbiaya murah dan mudah dilakukan.

\section{KESIMPULAN}

Kegiatan ini telah mendorong kreatifitas masyarakat untuk menghasilkan pupuk secara mandiri untuk mendukung pertanian berkelanjutan. Selain bermanfaat untuk memanfaatkan limbah yang selama ini menjadi masalah pencemaran lingkungan, kegiatan ini juga dapat mereduksi ketergantungan petani terhadap pupuk komersial yang berharga mahal dan ketersedian yang sering tidak berkesinambungan juga merintis kemandirian petani untuk memenuhi kebutuhannya sendiri. 


\section{UCAPAN TERIMA KASIH}

Ucapan terima kasih disampaikan kepada Bapak Muhammad Tahir (Kepala Desa Lepak Timur) yang telah membantu pelaksanaan kegiatan ini serta tokoh agama, tokoh masyarakat, tokoh pemuda, serta segenap peternak kambing PE di Desa Lepak Timur. Demikian pula kepada aparat pemerintahan Desa LepakTimur serta instansi terkait yang telah membantu kelancaran pelaksanaan kegiaytan ini.

\section{DAFTAR REFERENSI}

Adriani RN. 2014. Implementasi program one village one product (OVOP) pada koperasi paguyuban tenun troso Kabupaten Jepara. Departemen IImu Pemerintahan Fakultas IImu Sosial dan IImu Politik Universitas Diponegor, Semarang.

Ali M. 2016. Pengantar Bioteknologi. Mataram University Press, Mataram.

Ali M, Karni I., Amin M, and Ichsan M. 2018. Development of growth media for Bacillus amyloliquefaciens subsp. plantarum : a poultry probiotics candidate, J. Applied Biol. Sci., 12, 46-50.

Anonim, 2017. Laporan Kuliah Kerja Nyata (KKN) Desa Lepak Timur Kecamatan Sakra Timur Kabupaten Lombok Timur. Mataram.

Ichsan M., Ashari M., Ali M. 2016. Inovasi Bioteknologi Pengolahan Manur Ayam Petelur Untuk Menghasilkan Pupuk Bio-organik Baru Mengandung Plant Growth-Promoting Rhizobacteria (PGPR). Laporan Penelitian, Universitas Mataram, Mataram.

Islam S., Akanda AM., Prova A., Islam MT., and Hossain MM. 2016. Isolation and identification of plant growth promoting rhizobacteria from cucumber rhyzosphere and their effect on plant growth promotion and disease suppression. Frontiers in Microbiology, 6, 1360.

Padusung, 2015. Pengelolaan sumberdaya lahan pertanian ramah lingkungan menuju kedaulatan pangan, dalam: Revolusi Pangan, Regional Institute 104, Mataram. 